University of South Florida

DIGITAL COMMONS

Digital Commons @ University of

@ UNIVERSITY OF SOUTH FLORIDA

South Florida

$1-1-2010$

\title{
2010 Work Plan USF Polytechnic
}

USF

Follow this and additional works at: https://digitalcommons.usf.edu/usf_accountability_reports

\section{Scholar Commons Citation}

USF, "2010 Work Plan USF Polytechnic" (2010). USF Accountability Reports. 11.

https://digitalcommons.usf.edu/usf_accountability_reports/11

This Article is brought to you for free and open access by the USF Archives at Digital Commons @ University of South Florida. It has been accepted for inclusion in USF Accountability Reports by an authorized administrator of Digital Commons @ University of South Florida. For more information, please contact digitalcommons@usf.edu. 


\section{University Work Plan / Proposal}

\section{University of South Florida Polytechnic}

\section{Strategic Plan}

[Please provide a link to the latest version of the institution's strategic plan. If the latest strategic plan is not current, or the institution is in the process of developing or updating its strategic plan, please indicate at what stage the institution is in that process.]

http://www.poly.usf.edu/AboutUs/StrategicPlan.html

On June 25, 2007 the USF Polytechnic Campus Board approved the 2007-2012 Strategic Plan for presentation to the USF Board of Trustees which subsequently approved the plan on September 6, 2007. In October 2009, the USF Board of Trustees reaffirmed the USF Polytechnic 2007-2012 Strategic Plan to be a "premier destination campus for applied learning, research, and innovation technology."

\section{Mission Statement}

The University of South Florida Polytechnic is committed to excellence in interdisciplinary and applied learning; to the application of cutting-edge research and technology to real world needs; and to collaborative partnerships that support economic, social, and community development. 


\section{Overview of Core Institutional Strengths, Special Assets, and Niche Contributions}

To understand the University of South Florida's vision for its youngest campus - the University of South Florida Polytechnic - one must appreciate several parallel dynamics, all of which converge at the heart of Florida's High Tech Corridor, in Lakeland. These dynamics include the maturation of the USF System, the demographic pressures within the state of Florida, and economic development factors impacting central Florida as well as a broader context.

Despite a recent, very slight dip in population, Florida remains one of the states demographers project as a high growth state in the coming decades. This growth is a factor of in-migration from cooler climates to the north as well as immigration from Mexico, Central and South America, and the Caribbean. The resulting growth is already impacting the way the region is perceived: the widely cited economist and futurist, Richard Florida, has identified the Miami-Orlando-Tampa corridor as one of 40 "mega-regions that drive the world economy."

The state's economy has historically been driven by agriculture, tourism and real estate. Under Governor Jeb Bush, however, Florida designated its emerging core, anchored by I-4, as "Florida's High Tech Corridor." The FHTC leverages the resources of Tampa and Orlando, along with university powerhouses in Gainesville, Tampa and Orlando. And, perhaps most important, the FHTC's establishment has helped to focus those inside and outside the state on the tremendous potential of technology-driven economic development within Florida.

As Florida struggles to respond to a global economic crisis that has hit the state particularly hard, key visionaries in leadership roles have begun to articulate a vision for Florida's future. This emerging plan involves elegantly leveraging traditional strengths such as agriculture, transportation and real estate while also investing strategically in those highwage, knowledge-intensive sectors that have typically lagged behind in Florida.

In 2008, the Central Florida Development Council hired SRI International, an independent research firm, to conduct a detailed analysis of the region's current economic strengths and opportunities. The resulting "cluster analysis" study identified seven industry sectors that were already represented in the regional economy and primed for future growth: research \& engineering services; logistics \& supply chain management; life science \& medical services; education \& government; construction \& real estate; business \& financial services; and agriculture \& agritechnology.

As the region's public and private sectors mobilize to cultivate and exploit these clusters, USF has nurtured USF Polytechnic as the ideal higher education complement to central Florida's economic development initiatives. This process of aligning the institution's design with its socio-economic context has energized and synchronized USF Polytechnic and its key community stakeholders. It has also provided a distinct focus for the development of academic programs: each of the industry clusters maps directly to specific academic programs available or proposed for future development at USF Polytechnic. 


\section{Current Peer Institutions}

USF Polytechnic has selected three developmental peers: Arizona State University's Polytechnic Campus in Mesa, AZ; California Polytechnic State University in San Luis Obispo, CA; and the University of Wisconsin Stout Campus in Menomonie, WI.

- Arizona State University's Polytechnic Campus in Mesa, AZ is a public, suburban university established in 1996 as ASU East. In 2005 the campus name and mission were changed to ASU's Polytechnic Campus, serving more than 9,600 students in more than 40 undergraduate and master's degree programs.

- California Polytechnic State University in San Luis Obispo, CA is a public, suburban university established in 1901. It serves approximately 20,000 students offering numerous polytechnic bachelor's, master's and doctoral degrees.

- The University of Wisconsin Stout Campus in Menomonie, WI is a public, rural university established in 1971 as a regional campus in the University of Wisconsin System. In 2007 UW-Stout was designated “Wisconsin's Polytechnic University" by the UW System Board of Regents with a mission as a "comprehensive, career-focused polytechnic where students, faculty and staff use applied learning, scientific theory and research to solve real-world problems, grow the state economy and serve society." UW Stout currently serves 8,800 students offering 50, primarily undergraduate and master, degrees.

Aspirational Peer Institutions (aspire and plan to be comparable to in the next 5 - 10 years) USF Polytechnic also selected two aspirational peers: Rensselaer Polytechnic Institute and Virginia Polytechnic \& State University (Virginia Tech).

- Rensselaer Polytechnic Institute in Troy, NY is a private, urban university established in 1824. It serves approximately 7,300 students offering bachelor's, master's and doctoral degrees in many of the science, technology, engineering, and mathematic areas.

- Virginia Tech in Blacksburg, VA is a public, rural university established in 1872. It serves approximately 30,000 students with a strong emphasis on polytechnic bachelor's, master's and doctoral degrees. 


\section{Institutional Vision and Strategic Directions for the Next 5 - 10 Years}

As the USF System has evolved, it has dramatically expanded access to Florida residents and highly motivated students from around the world. The diversity of its four campuses will continue to accommodate the development of distinctive models of higher education - what the USF Board of Trustees has described as "mission differentiation" - to serve the current and emerging education, research and economic development needs of the state, nation and world.

Such is the context within which the University of South Florida chose to act, with the creation of USF Polytechnic. Florida has clearly emerged as a diverse, high-growth population center - a micro-economy comparable to significant international counterparts. Central Florida has identified an array of fertile economic clusters, worthy of cultivation. In response to these factors, USF developed what has since been described by Florida Governor Charlie Crist as "Florida's first and only polytechnic."

While the polytechnic model itself is not new, it is relatively new to the southeastern United States - and thoroughly novel to Florida's public higher education system. The word "polytechnic" is derived from a Greek term which translates, literally, as "skilled in many arts." As implemented by USF Polytechnic, a "polytechnic" education is peculiar in method as well as substance. In other words, polytechnics are distinguished both in what they do and how they do it. USF Polytechnic will also be distinguished contextually, as it develops an extraordinary campus environment at its new campus site.

Methodologically, polytechnics focus on applied, multi-disciplinary learning and research. Learning environments are created to facilitate hands-on, collaborative problem solving and inquiry. Learning experiences include problem-based applications, field experiences, practica and internships. Rather than basic, theoretical research, polytechnics focus on the practical application of existing knowledge to solve tangible problems and provide tangible social benefits. Rather than reifying the "silo" paradigm so common in American higher education, polytechnics orient scholarship collaboratively in a relentless pursuit of cross-disciplinary synergies and innovation.

Substantively, polytechnics tend to cultivate strengths in the applied scientific and professional fields, such as engineering, sciences, business and education. Traditional "liberal arts" disciplines are not absent from the curriculum but are often delivered within the context of the general education curricula and embedded in the multi-disciplinary, applied discovery characteristic of the polytechnic experience.

Contextually, USF Polytechnic's I-4 campus is being developed as a unique "bioscape," designed by world-renowned architect, Dr. Santiago Calatrava. The campus context will emerge as an unprecedented synthesis of architecture, design, engineering, agriculture and sustainability - a living example of the research, academic and social missions of USF Polytechnic.

The vision of a polytechnic model was not conceived overnight, and its full potential will not be realized overnight. As the Campus Master Plan, approved by the USF Board of Trustees on March 7, 2007 and updated, amended and approved by the Board of Trustees on October 27, 2009, indicates, USF Polytechnic will continue growing and developing through 2025.

The very economic pressures that have created an imperative for innovation also intensify the pursuit of the resources necessary to implement the polytechnic model - a model that is admittedly more expensive to implement and operate than traditional higher educational paradigms. This reality, along with the sheer logistical challenges of building an institution from scratch (physically as well as programmatically), have dictated a phased approach for the remaining implementation of the USF Polytechnic 2007-2012 Strategic Plan. 


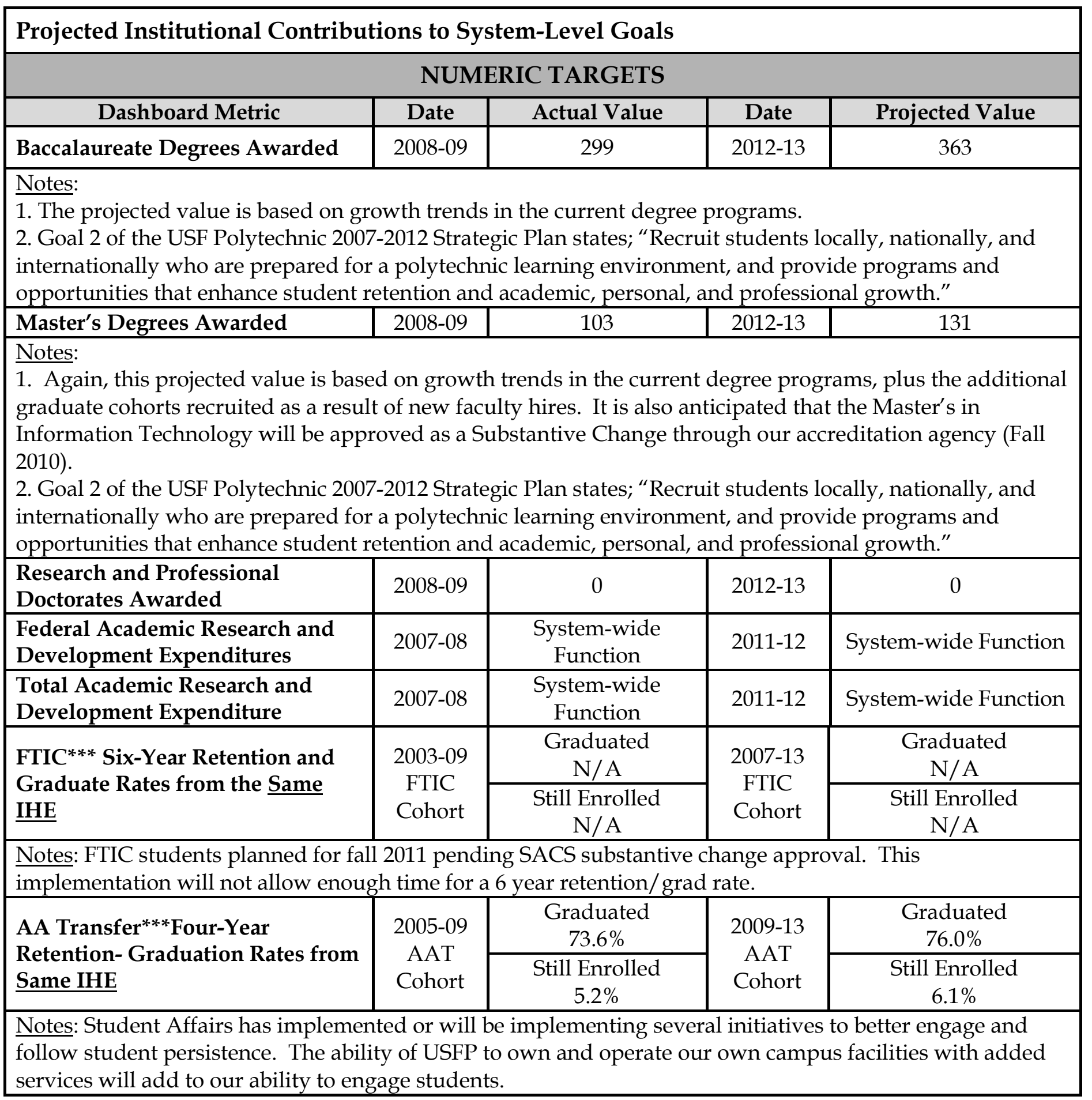


DIRECTIONAL TARGETS [Indicate Direction: I=Increase, M=Maintain, D=Decrease]

\begin{tabular}{|c|c|c|c|c|c|c|}
\hline Dashboard Metric & Date & \multicolumn{2}{|c|}{ Actual Value } & Date & \multicolumn{2}{|c|}{ Projected Direction** } \\
\hline \multirow{2}{*}{$\begin{array}{l}\text { Baccalaureate Degrees Awarded } \\
\text { to Black, Non-Hispanics }\end{array}$} & \multirow{2}{*}{ 2008-09 } & \# & $\%$ * & \multirow{2}{*}{ 2012-13 } & \# & $\% *$ \\
\hline & & 35 & $11.7 \%$ & & I & M \\
\hline
\end{tabular}

Notes: Goal 2.3 of the USFP 2007-12 Strategic Plan states; “Recruit, retain and graduate higher numbers of

underrepresented students in both undergraduate and graduate programs". While the number will increase, it will be in proportion to the overall increase in degrees awarded.

\begin{tabular}{|l|c|c|c|c|c|c|}
\hline $\begin{array}{l}\text { Baccalaureate Degrees Awarded } \\
\text { to Hispanics }\end{array}$ & \multirow{2}{*}{$2008-09$} & $\#$ & $\%^{*}$ & \multirow{2}{*}{$2012-13$} & $\#$ & $\%^{*}$ \\
\cline { 3 - 4 } \cline { 5 - 7 } & & 28 & $9.3 \%$ & & $\mathrm{I}$ \\
\hline
\end{tabular}

Notes: Goal 2.3 of the USFP 2007-12 Strategic Plan states; "Recruit, retain and graduate higher numbers of underrepresented students in both undergraduate and graduate programs". Our enrollment of Hispanic students has increased or maintained over the last four years and it is anticipated to increased based on the enrollment pool.

\begin{tabular}{|l|c|c|c|c|c|c|}
\hline Baccalaureate Degrees Awarded & \multirow{2}{*}{$2008-09$} & $\#$ & $\%^{*}$ & \multirow{2}{*}{$2012-13$} & $\#$ & $\%^{*}$ \\
\cline { 3 - 4 } & & 28 & $9.5 \%$ & & $\mathrm{I}$ & $\mathrm{M}$ \\
\hline
\end{tabular}

Notes: Goal 2.7 of the USFP 2007-12 Strategic Plan states; "Increase scholarships available for students." The growth is anticipated to stay in proportion to the growth in degrees awarded for this time period.

\begin{tabular}{l|c|c|c|c|c|c|c}
\hline \multirow{2}{*}{$\begin{array}{l}\text { Degrees Awarded in Specified } \\
\text { STEM Fields }\end{array}$} & \multirow{2}{*}{$2008-09$} & Bacc. & Grad. & \multirow{2}{*}{$2012-13$} & Bacc. & Grad. \\
\cline { 3 - 4 } \cline { 5 - 7 } & & 19 & 0 & & I \\
\hline
\end{tabular}

Notes: USF Polytechnic's entire strategic plan emphasizes graduating students who are suited for STEM fields. Many more of these degrees are under development and will expand during the 2012-13 academic year with SACS accreditation.

\begin{tabular}{|l|c|c|c|c|c|c|}
\hline $\begin{array}{l}\text { Degrees Awarded Specified } \\
\text { Health Profession Critical Need } \\
\text { Areas }\end{array}$ & \multirow{2}{*}{$2008-09$} & Bacc. & Grad. & \multirow{2}{*}{$2012-13$} & Bacc. & Grad. \\
\cline { 3 - 4 } \cline { 5 - 7 } & & 7 & 2 & & I & M \\
\hline
\end{tabular}

Notes: The degrees awarded in health professions are limited now, but will grow with SACS accreditation - especially in the Bachelorette degrees. One of the five areas of distinction within the USFP Strategic Plan (goal 3) is; "applied health sciences".

\begin{tabular}{|l|c|c|c|c|c|c|}
\hline $\begin{array}{l}\text { Degrees Awarded in Specified } \\
\text { Education Critical Need Areas }\end{array}$ & \multirow{2}{*}{$2008-09$} & Bacc. & Grad. & \multirow{2}{*}{$2012-13$} & Bacc. & Grad. \\
\cline { 3 - 4 } \cline { 5 - 7 } & & 0 & 29 & & I & I
\end{tabular}

Notes: USF Polytechnic's educational degrees are expanding in "mathematics and science education" as part of Goal 3 of the USFP Strategic Plan.

\begin{tabular}{|c|c|c|c|c|}
\hline $\begin{array}{l}\text { NCLEX Pass Rate First-Time Test } \\
\text { Takers Bacc. Nursing Program }\end{array}$ & 2008 & $\mathrm{~N} / \mathrm{A}$ & 2012 & $\mathrm{~N} / \mathrm{A}$ \\
\hline Licensing Income & 2007-08 & $\mathrm{N} / \mathrm{A}$ & 2011-12 & $\mathrm{N} / \mathrm{A}$ \\
\hline Licenses and Options Executed & 2007-08 & $\mathrm{N} / \mathrm{A}$ & 2011-12 & $\mathrm{N} / \mathrm{A}$ \\
\hline \multirow{2}{*}{$\begin{array}{l}\text { Other Transfer }{ }^{* *} \text { Five-Year } \\
\text { Retention and Graduation Rates } \\
\text { from the Same IHE }\end{array}$} & \multirow{2}{*}{$\begin{array}{c}\text { 2004-09 } \\
\text { Other } \\
\text { Cohort }\end{array}$} & $\begin{array}{c}\text { Graduated } \\
58.6 \%\end{array}$ & \multirow{2}{*}{$\begin{array}{l}2008-13 \\
\text { Other } \\
\text { Cohort }\end{array}$} & $\begin{array}{l}\text { Graduated } \\
\text { I }\end{array}$ \\
\hline & & $\begin{array}{c}\text { Still Enrolled } \\
5.2 \%\end{array}$ & & $\begin{array}{c}\text { Still Enrolled } \\
M\end{array}$ \\
\hline
\end{tabular}

Notes: The cohort for "Other Transfers" is small and will grow with lower level classes (fall 2011). As a System, these students will have an easier time transferring to other USF campuses. This, in effect, makes this metric harder to predict.

"Actual Value" should equal related value in 2009 Annual Report.

* Percentage of Total Baccalaureates Awarded That Were Awarded to Specific Group.

** Projected Direction = INCREASE, MAINTAIN, or DECREASE. 


\begin{abstract}
Additional Primary Institutional Goals/Metrics for the Next One to Three Years
(In the context of the institutional strategic plan and vision, as well as System priorities, present a minimum of three additional goals on which university effort will be focused in the next one to three years. Describe each goal, including whether the goal is new or continuing, the strategy for achieving that goal, the metrics by which success will be measured, specific actions to be taken in this fiscal year, expected outcomes, and assumptions, including financial, upon which the projected outcomes are predicated.)

Separate SACS Accreditation: In June 2010 USF Polytechnic will submit its initial application for accreditation. With acceptance of the application, USFP will work on the SACS Compliance Certification during 2010-2011. In addition, USFP will be preparing for its SACS accreditation peer review and the onsite review planned for March 2011 or September 2011. In 2011-2012 USFP will complete SACS Compliance Certification with the on-site review. Throughout this time, a focus will be on increasing enrollment, completion of the USF System approval process for the new targeted "polytechnic" degrees, completion of a faculty and staff hiring plan to support the approved new degree programs and FTIC enrollment, and continue identification of increased revenue sources. A new strategic planning process will be implemented to develop a 2012-2018 Strategic Plan. The Campus Master Plan will be updated to complement the new strategic plan.

Faculty and Staff Hiring Plans: Critical to successful completion of initial SACS accreditation is the identification and implementation of a faculty and staff hiring plan to build depth in existing faculty, capacity for delivery of existing degree programs, and additional support for student services. As accreditation is achieved, faculty and staff hiring plans will focus on capacity for delivery of the new "polytechnic" degrees and additional capacity for full implementation of general education offerings for Freshman and Sophomore classes.
\end{abstract}

Emphasis in faculty hiring is the identification of practitioner-scholars with capacity to deliver the polytechnic vision in teaching, research, and community engagement and impact. We will be seeking faculty who have academic degrees from polytechnic or polytechnic-like universities or experience working in polytechnic or polytechnic-like universities.

Master Plan: With the new polytechnic focus and the advent of a signature design for the Phase I facility on the new campus, USF Polytechnic announced that the Architect/Engineer RFP would include the opportunity to update the existing Master Plan which was developed in 2005-06 and approved in 2007. The campus engaged a world-class architect, Dr. Santiago Calatrava, a product of several polytechnic universities in Europe, who brings his personal experiences to the design. The Master Plan update allows for the exposure of the first facilities to the tens of thousands of travelers along Interstate 4 and will align the campus facilities to provide for the synergistic environment conducive to the polytechnic experience for our students. It will also employ measures to ensure a focus on sustainability and the natural environment. In addition, the USFP's vision as a destination campus, included in the 2007-2012 Strategic Plan, will require a carefully planned and phased in approach to the development of on-campus residence halls and appropriate amenities needed to provide for residential student's physical, social, intellectual and community engagement opportunities.

Polytechnic Academic Programs: While no new degree programs can be implemented until completion of SACS accreditation, new degree programs can be developed and taken through the USF System program approval process for implementation after SACS accreditation with required notification of substantive change. These new degree programs would be targeted for implementation in fall 2012 with the opening of the new campus site. The initial identification of new degree programs has been carefully aligned with industry sectors identified by SRI International and Enterprise Florida as prime for future cultivation and growth. In addition, all programs will place emphasis on applied learning where students and faculty engage in interactive, problem- and solution-based learning and applications of innovative research and technology. Initial polytechnic program development and submission for approval would be completed during 2010-2012. 


\begin{tabular}{|c|c|c|c|c|}
\hline \multicolumn{5}{|c|}{$\begin{array}{l}\text { New Academic Degree Program Proposals - Next Three Years (Program development } \\
\text { goals need to align with the institutional strategic plan and System priorities.) }\end{array}$} \\
\hline $\begin{array}{c}\text { Proposed Date } \\
\text { of Submission to } \\
\text { University Board } \\
\text { of Trustees }\end{array}$ & $\begin{array}{c}\text { Program } \\
\text { Level }\end{array}$ & $\begin{array}{l}\text { 6-Digit } \\
\text { CIP } \\
\text { Code }\end{array}$ & Program Title & $\begin{array}{c}\text { Comments } \\
\text { (Including Proposed } \\
\text { Implementation Date) }\end{array}$ \\
\hline 2011 & UG & 14.1701 & Manufacturing Engineering & \multirow{12}{*}{$\begin{array}{l}\text { Degrees will not be } \\
\text { offered until completion } \\
\text { of SACS accreditation and } \\
\text { opening of new I- } 4 \\
\text { campus site. }\end{array}$} \\
\hline 2011 & UG & 15.0603 & $\begin{array}{l}\text { Manufacturing Engineering } \\
\text { Technology }\end{array}$ & \\
\hline 2012 & GR & 14.1701 & Manufacturing Engineering & \\
\hline 2012 & UG & 14.0301 & $\begin{array}{l}\text { Agricultural/Biological } \\
\text { Engineering }\end{array}$ & \\
\hline 2012 & UG & 50.0706 & Digital Arts/Digital Design & \\
\hline 2012 & UG & 04.0201 & Architecture & \\
\hline 2012 & UG & New & $\begin{array}{l}\text { Communication Sciences and } \\
\text { Technologies }\end{array}$ & \\
\hline 2012 & $\begin{array}{l}\text { UG \& } \\
\text { GR }\end{array}$ & New & Integrated STEM Education & \\
\hline 2012 & $\begin{array}{l}\text { UG \& } \\
\text { GR }\end{array}$ & New & $\begin{array}{l}\text { Technology Mediated } \\
\text { Learning }\end{array}$ & \\
\hline 2012 & UG & New & Interdisciplinary Engineering & \\
\hline 2012 & UG & New & Design & \\
\hline 2012 & UG & New & Forensic Science Studies & \\
\hline
\end{tabular}




\section{Windows of Opportunity/Unique Challenges}

(If the university has been presented with one or more unique opportunities that have not been included in prior plans but which will receive particular attention during this year, those opportunities should be presented here. Additionally, if the university expects to face a unique challenge in the coming year(s), that should be noted.)

- USF Polytechnic's vision as a destination campus, included in the 2007-2012 Strategic Plan, will require a carefully planned and phased in approach to the development of on-campus residence halls and appropriate amenities needed to provide for residential students' physical, social, intellectual and community engagement opportunities.

- As budget becomes available, as facilities are constructed, and following all requirements of SACS accreditation, USF Polytechnic will continue to develop 2012 and beyond a faculty and staff hiring plan to enable delivery of FTIC, new degree programs, research and community engagement initiatives to transition strategically over time to the polytechnic model.

- A strategy for the development of the General Education core is expected to focus on a narrow number of course offerings, aligned with the USF Polytechnic Core Values as identified in the 2007-2012 Strategic Plan. This will enable USFP to deliver general education that meets State requirements, demonstrates measurable performance-based competencies, and includes fieldbased and internship experiences for all students with fewer course offerings.

- A concurrent strategy for faculty hiring is expected to focus on addition of faculty in English, mathematics and statistics, natural sciences, life sciences, humanities, political science and international affairs. Staff hiring will continue to target support for Student Affairs and academic program support. When USF Polytechnic prepares for the occupancy of the first facility on the new campus site, staff hiring will also target campus operations, maintenance, safety and security. 
Tuition Differential Proposal for 2010-2011

University: University of South Florida Polytechnic

\section{Effective Date}

University Board of Trustees Approval Date:

Implementation Date (month/year):

August 2010

\section{Purpose}

Describe the overall purpose of the tuition differential at this institution and the aspects of undergraduate education the funds are intended to improve.

To preserve course offerings that would otherwise have been eliminated in response to budget cuts.

\section{Campus or Center Location}

Campus or Center Location to which the Tuition Polytechnic

Differential fee will apply. (If the entire university, indicate as such.)

\section{Undergraduate Course(s)}

Course(s). (If the tuition differential fee applies to all university undergraduate courses, indicate as such. If not, also provide a rationale for the differentiation among courses.)

The tuition differential will apply to all undergraduate courses offered by the USF System

\section{Current Base Tuition and Tuition Differential Fee}

Current (2010-11) Undergraduate Base Tuition per credit hour:

Current Undergraduate Tuition Differential per credit hour:
$\$ 95.67$

$\$ 12.80$

\section{Proposed Increase in the Tuition Differential Fee}

Percentage tuition differential fee increase (calculated as a percentage of the sum of base tuition plus tuition differential):

$\$$ Increase in tuition differential per credit hour: $\$$ Increase in tuition differential for 30 credit hours:

$7 \%$ $\$ 7.06$ $\$ 211.80$ 


\section{Projected Differential Revenue Generated and Intended Uses}

Incremental differential fee revenue generated in 2010-11 (projected): $\$ 200,150$

Total differential fee revenue generated in 2010-11 (projected): $\$ 331,699$

Seventy percent $\mathbf{( 7 0} \%)$ of the total differential revenue generated must be used for undergraduate education. The total estimated amount to be spent on undergraduate education is $\$ 232,189$.

Describe in detail the initiative(s) and the estimated expenditure(s) for each:

1. Increase course offerings.

2. Improve graduation rates through timely information on student progress.

3. Improve advising/counseling to enhance the delivery of undergraduate education.

Thirty percent (30\%) of the total differential revenue generated must be used for undergraduate students who have financial need. Total estimated amount to be spent on financial need is $\$ 90,154$. If private sources are to be used, then the estimated amount of private dollars to be raised to offset the fee revenue is \$ USF SYSTEM.

Managed at the USF System level (see USF System work plan)

\section{Monitoring}

Indicate how the university will monitor the success of the tuition differential fee. Provide specific performance metrics that will be used. Also, point out any metrics that are different from the prior year and any prior year metrics that are no longer listed.
1. Increase in course offerings.

2. Progress toward degree

3. Advising/counseling enhancements

\section{Performance Measure Status}

What is the institution's plan for improving performance on the identified measure(s)? Show initial/baseline data starting with the year before each metric was identified, the goal for each metric, time frame for achieving the goal, and where the institution is now in relation to the goal if not in the initial year.
1. USF Polytechnic's estimated tuition differential revenue for $2009-10$ was $\$ 82,537$. Initiatives undertaken included increasing course offerings $(\$ 52,537)$ \& increasing the $\%$ of students in UG majors who were taught by FT faculty (\$30K). 20010-11 target is $\$ 214,253$ achievable by the end of the academic year through similar initiatives as 2009-10. 


\section{Tuition Differential Supplemental Information}

Provide the following information for the 2009-2010 academic year.

\section{9-2010 - 70\% Initiatives (List the initiatives provided in} the 2009-10 tuition differential request.)

Increase Course offerings

Improve graduation rates through timely information on student progress

Improve advising/counseling to enhance the delivery of undergraduate education
University Update on Each Initiative

23 course offerings (fall/spring)

Additional course offerings improved progress toward degree

Expect to improve this initiative in 2010-11

\section{Additional Detail, where applicable}

\begin{tabular}{|l|l|}
\hline Number of Faculty Hired (funded by tuition differential): & 10 PT \\
\hline Number of Advisors Hired (funded by tuition differential): & 0 \\
\hline $\begin{array}{l}\text { Number of Course Sections Added (funded by tuition } \\
\text { differential): }\end{array}$ & 28 \\
\hline
\end{tabular}

2009-2010 - 30\% Initiatives (List the initiatives provided in the 2009-10 tuition differential request.)

University Update on Each Initiative

Managed at the USF System level (see USF System work plan)

\section{Additional Information (estimates as of April 30, 2010)}

Unduplicated Count of Students Receiving at least one

Tuition Differential-Funded Award:

$\$$ Mean (per student receiving an award) of Tuition

Differential-Funded Awards:

Managed at the USF System level (see USF System work plan)

\$ Minimum (per student receiving an award) of Tuition Differential-Funded Awards:

\$ Maximum (per student receiving an award) of Tuition

Differential-Funded Awards: 


\section{STATE UNIVERSITY SYSTEM OF FLORIDA}

Tuition Differential Collections, Expenditures, and Available Balances

University: University of South Florida Polytechnic

\section{Fiscal Year 2009-2010 and 2010-11}

\section{University Tuition Differential}

Budget Entity: 48900100 (Educational \& General)

SF/Fund: 2 164xxx (Student and Other Fees Trust Fund)

\section{Estimated Actual*}

2009-10

\section{Balance Forward from Prior Periods}

Balance Forward

$\begin{array}{r}\$ 0 \\ 0 \\ \hline \$ 0\end{array}$

Beginning Balance Available:

\section{$\underline{\text { Receipts / Revenues }}$}

Tuition Differential Collections

Interest Revenue - Current Year

Interest Revenue - From Carryforward Balance

Total Receipts / Revenues:

\section{Expenditures}

Salaries \& Benefits

Other Personal Services

Expenses

Operating Capital Outlay

Student Financial Assistance

Expended From Carryforward Balance

** Other Category Expenditures

Total Expenditures:

Ending Balance Available:

*Since the 2009-10 year has not been completed, provide an estimated actual.

**Provide details for "Other Categories" used. 
Enrollment Plan Proposal (May need to be submitted later than the rest of the Work Plan)

USF Polytechnic

\begin{tabular}{|c|c|c|c|c|c|c|c|c|}
\hline $\begin{array}{c}\text { For entire } \\
\text { institution }\end{array}$ & Funded & Estimated & Funded & Estimated & Estimated & Estimated & Estimated & $\begin{array}{c}5-Y e a r \\
\text { Projected }\end{array}$ \\
\hline FTE & 2009-10 & 2009-10 & 2010-11 & 2010-11 & 2011-12 & 2013-14 & 2015-16 & $\begin{array}{c}\text { Annual } \\
\text { Growth } \\
\text { Rate }\end{array}$ \\
\hline $\begin{array}{l}\text { FL Resident } \\
\text { Lower }\end{array}$ & - & 51 & - & 53 & 89 & 307 & 460 & $153.6 \%$ \\
\hline $\begin{array}{l}\text { FL Resident } \\
\text { Upper }\end{array}$ & 494 & 747 & 494 & 814 & 906 & 1,188 & 1,670 & $21.0 \%$ \\
\hline $\begin{array}{l}\text { FL Resident } \\
\text { Grad I }\end{array}$ & 103 & 105 & 103 & 125 & 129 & 139 & 152 & $4.3 \%$ \\
\hline $\begin{array}{l}\text { FL Resident } \\
\text { Grad II }\end{array}$ & - & - & - & - & - & - & - & \\
\hline $\begin{array}{r}\text { Total FL } \\
\text { Resident } \\
\end{array}$ & 597 & 904 & 597 & 992 & 1,124 & 1,634 & 2,282 & $26.0 \%$ \\
\hline & & & & - & - & - & - & \\
\hline $\begin{array}{l}\text { Non-res } \\
\text { Lower }\end{array}$ & & 1 & & - & 3 & 8 & 10 & \\
\hline $\begin{array}{l}\text { Non-res } \\
\text { Upper }\end{array}$ & & 7 & & 9 & 9 & 12 & 16 & $15.6 \%$ \\
\hline $\begin{array}{l}\text { Non-res } \\
\text { Grad I }\end{array}$ & & - & & 1 & 1 & 2 & 3 & $40.0 \%$ \\
\hline $\begin{array}{l}\text { Non-res } \\
\text { Grad II }\end{array}$ & & - & & - & - & - & - & \\
\hline $\begin{array}{l}\text { Total Non- } \\
\text { res }\end{array}$ & & 8 & & 10 & 13 & 22 & 29 & $38.0 \%$ \\
\hline Total Lower & - & 52 & - & 53 & 92 & 315 & 470 & $157.4 \%$ \\
\hline Total Upper & 494 & 754 & 494 & 823 & 915 & 1,200 & 1,686 & $21.0 \%$ \\
\hline Total Grad I & 103 & 105 & 103 & 126 & 130 & 141 & 155 & $4.6 \%$ \\
\hline Total Grad II & - & - & - & - & - & - & - & \\
\hline Total FTE & 597 & 912 & 597 & 1,002 & 1,137 & 1,656 & 2,311 & $26.1 \%$ \\
\hline
\end{tabular}


For each distinct location (main, branch, site, regional campus) that has or is planned to have more than 150 FTE SITE: Polytechnic

\begin{tabular}{|c|c|c|c|c|c|c|c|c|}
\hline $\begin{array}{l}\text { For entire } \\
\text { institution }\end{array}$ & Funded & Estimated & Funded & Estimated & Estimated & Estimated & Estimated & $\begin{array}{c}\text { 5-Year } \\
\text { Projected }\end{array}$ \\
\hline FTE & 2009-10 & $2009-10$ & $2010-11$ & 2010-11 & 2011-12 & 2013-14 & $2015-16$ & $\begin{array}{c}\text { Annual } \\
\text { Growth } \\
\text { Rate }\end{array}$ \\
\hline Total Lower & - & 52 & - & 53 & 92 & 315 & 470 & $157.4 \%$ \\
\hline Total Upper & 494 & 754 & 494 & 823 & 915 & 1,200 & 1,686 & $21.0 \%$ \\
\hline Total Grad I & 103 & 105 & 103 & 126 & 130 & 141 & 155 & $4.6 \%$ \\
\hline Total Grad II & - & - & - & - & - & - & - & \\
\hline Total FTE & 597 & 912 & 597 & 1,002 & 1,137 & 1,656 & 2,311 & $26.1 \%$ \\
\hline
\end{tabular}

